\title{
Spatiotemporal distribution of Vibrio parahaemolyticus in relation to environmental parameters in a coastal lagoon on the Pacific coast of northwestern Mexico
}

\section{Distribución espaciotemporal de Vibrio parahaemolyticus con relación a los parámetros ambientales en una laguna costera en la costa del Pacífico del noroeste de México}

\author{
Ana M Rivas-Montaño ${ }^{1,2}$, Irasema E Luis-Villaseñor ${ }^{1 *}$, Pablo Piña-Valdez ${ }^{1}$, Bruno Gómez-Gil ${ }^{3}$, \\ Marcial L Lizárraga-Partida ${ }^{4}$
}

${ }^{1}$ Facultad de Ciencias del Mar, Universidad Autónoma de Sinaloa, Paseo Claussen, s/n, Colonia Los Pinos, CP 80000, Mazatlán, Sinaloa, Mexico.

2 Instituto Tecnológico de Mazatlán (ITMAZ), no. 203, Colonia Urías, CP 82070, Mazatlán, Sinaloa, Mexico.

${ }^{3}$ Centro de Investigación en Alimentación y Desarrollo, Av. Sábalo Cerritos, s/n, CP 82100, Mazatlán, Sinaloa, Mexico.

${ }^{4}$ Centro de Investigación Científica y de Educación Superior de Ensenada Baja California, Carretera EnsenadaTijuana, no. 3918, Zona Playitas, CP 22860, Ensenada, Baja California, Mexico.

* Corresponding author. E-mail: irasemaluis@uas.edu.mx

\begin{abstract}
Vibrio parahaemolyticus has been responsible for the increasing number of diarrhea cases in Sinaloa, Mexico, since 2003. We investigated the presence, distribution, and content of V. parahaemolyticus toxigenic genes detected in water, zooplankton, and sediment samples in relation to environmental variables in Caimanero Lagoon (Mazatlán, Sinaloa). Samples were analyzed by PCR to detect the presence of V. parahaemolyticus and its toxigenic factors. Of all the samples analyzed, 57.5\% tested positive for thermolabile hemolysin (tlh), a gene indicative of the species. The thermostable direct hemolysin $(t d h)$ and $t d h$-related hemolysin $(t r h)$ genes, which are both pathogenicity markers of this species, were detected in $9 \%$ and $6 \%$ of the samples, respectively. The orf f fragment, which has been recently detected in pandemic strains (O3:K6), was detected in 11\% of the samples. Vibrio parahaemolyticus was detected more frequently in zooplankton, with the highest incidence observed in February. Salinity was positively correlated with V. parahaemolyticus; however, no correlation was found between V. parahaemolyticus and temperature. The presence of toxigenic V. parahaemolyticus during the different seasons indicates the need to maintain continuous sanitary inspection of fish products from Caimanero Lagoon.
\end{abstract}

Key words: coastal lagoon, pathogenic genes, Vibrio parahaemolyticus, environmental parameters.

Resumen. Vibrio parahaemolyticus ha sido responsable del creciente número de casos de diarrea en Sinaloa, México, desde 2003. Investigamos la presencia, la distribución y el contenido de los genes toxigénicos de V. parahaemolyticus que fueron detectados en muestras de agua, zooplancton y sedimento y su relación con las variables ambientales en la laguna Caimanero (Mazatlán, Sinaloa). Las muestras fueron analizadas por reacción en cadena de la polimerasa para detectar la presencia de V. parahaemolyticus y sus factores toxigénicos. De todas las muestras analizadas, el $57.5 \%$ resultaron positivas para la hemolisina termolábil (tlh), un gen indicativo de la especie. Los genes de la hemolisina directa termoestable $(t d h)$ y la hemolisina relacionada a la $t d h(t r h)$, considerados marcadores de la patogenicidad de la especie, fueron detectados en el $9 \%$ y el $6 \%$ de las muestras, respectivamente. El fragmento orf8, que recientemente se ha detectado en cepas pandémicas (O3:K6), se detectó en el $11 \%$ de las muestras. Vibrio parahaemolyticus fue detectado con mayor frecuencia en el zooplancton, con la incidencia más alta observada en febrero. La salinidad se correlacionó positivamente con V. parahaemolyticus; sin embargo, no se registró correlación entre V. parahaemolyticus y la temperatura. La presencia de $V$. parahaemolyticus toxigénico durante las diferentes temporadas indica la necesidad de mantener la vigilancia sanitaria continua de los productos pesqueros de la laguna Caimanero.

Palabras clave: laguna costera, genes patógenos, Vibrio parahaemolyticus, parámetros ambientales.

\section{INTRODUCTION}

The genus Vibrio currently contains 147 species (Parte 2018), some of which are pathogenic to humans, for example Vibrio parahaemolyticus, Vibrio vulnificus, and

\section{INTRODUCCIÓN}

Actualmente, el género Vibrio contiene 147 especies (Parte 2018), algunas de las cuales son patógenas para los humanos, por ejemplo, Vibrio parahaemolyticus, Vibrio vulnificus y 
Vibrio cholerae (Kaysner and DePaola 2004, Johnson 2013). The members of this genus are free-living microorganisms that are found in marine and estuarine water and sediment habitats, but they can also be associated with the fishes, bivalves, or plankton in an ecosystem (Cariani et al. 2012, Ottaviani et al. 2013, Givens et al. 2014).

Vibrio parahaemolyticus (Fugino et al. 1951) is a major causative agent of gastroenteritis in humans following ingestion of contaminated raw shellfish (Paranjpye et al. 2012, Wang et al. 2015). The symptoms of $V$. parahaemolyticus infection include diarrhea with abdominal pain, nausea, vomiting, headache, and fever (FAO/WHO 2011, Letchumanan et al. 2014). Thermostable direct haemolysin (tdh) and tdh-related haemolysin (trh) are the primary pathogenic factors that have been identified in $V$. parahaemolyticus (Zhang and Orth 2013, Ceccarelli and Colwell 2014). Since 1996 outbreaks of $t d h+/ O 3:$ K6 V. parahaemolyticus infections have been recorded in Asia (Miyoshi 2013, ChungSaint et al. 2016), Europe (Martinez-Urtaza et al. 2016), the United States (Xu et al. 2015), and Latin America (Gavilán and Martínez 2011, García et al. 2013, Velazquez-Roman et al. 2014).

In Mexico, toxigenic V. parahaemolyticus has been reported primarily in the state of Veracruz, near the Gulf of Mexico. Flores-Primo et al. (2014) and López-Hernández (2015) reported the presence of V. parahaemolyticus in oysters growing in the coastal lagoons of Veracruz. Coastal lagoons along the Pacific coast of Mexico, on the other hand, have been less studied than those along the shoreline of the Gulf of Mexico. In 2004, more than 1,230 $V$. parahaemolyticus $\mathrm{O} 3: \mathrm{K} 6$ clinical gastroenteritis cases were recorded after the consumption of raw shrimp from the Huizache-Caimanero lagoon system (Sinaloa, Mexico) (Cabanillas-Beltrán et al. 2006). The Caimanero and Huizache lagoons support an important artisanal shrimp fishery, the products of which are distributed to restaurants in tourist areas in the state of Sinaloa and other states in Mexico. The Huizache-Caimanero lagoon system is characterized by extreme salinity fluctuations (between 3 and 60 ), a seawater temperature range of 20 to $30^{\circ} \mathrm{C}$, and an intermittent input of non-native nutrients (De la Lanza and Rodríguez 1990). Overfishing and eutrophication by effluents loaded with nutrients from shrimp farms in the Huizache and Caimanero areas have contributed to changes in the natural ecological conditions of the lagoons and have thus affected the distribution and abundance of microbial populations, including those of bacteria (Beltrán-Pimienta and Retamoza-Leyva 2003, Romero-Beltrán et al. 2014). Bacterial associations with nutrient-rich effluents have also been observed in agricultural activities in other parts of Sinaloa (Ahumada-Santos et al. 2014). This study aimed to determine the presence and distribution of $V$. parahaemolyticus, its toxigenic variants, and its relation to environmental variables in Caimanero Lagoon.
Vibrio cholerae (Kaysner y DePaola 2004, Johnson 2013). Los miembros del género Vibrio son microorganismos de vida libre que se encuentran en aguas marinas y estuarinas y en hábitats de sedimento, pero también se pueden relacionar con los peces, los bivalvos o el plancton en un ecosistema (Cariani et al. 2012, Ottaviani et al. 2013, Givens et al. 2014).

Vibrio parahaemolyticus (Fugino et al. 1951) es un agente causal principal de la gastroenteritis en humanos después de la ingesta de mariscos crudos contaminados (Paranjpye et al. 2012, Wang et al. 2015). Los síntomas de una infección por $V$. parahaemolyticus incluyen diarrea con dolor abdominal, nausea, vomito, dolor de cabeza y fiebre (FAO/WHO 2011, Letchumanan et al. 2014). La hemolisina directa termoestable $(t d h)$ y la hemolisina relacionada a la $t d h(t r h)$ son los principales factores patogénicos que se han identificado en V. parahaemolyticus (Zhang y Orth 2013, Ceccarelli y Colwell 2014). Desde 1996 se han registrado brotes de infecciones por tdh+/O3:K6 de V. parahaemolyticus en Asia (Miyoshi 2013, Chung-Saint et al. 2016), Europa (Martinez-Urtaza et al. 2016), los Estados Unidos (Xu et al. 2015) y Latinoamérica (Gavilán y Martínez 2011, García et al. 2013, Velazquez-Roman et al. 2014).

En México, la detección de $V$. parahaemolyticus toxigénico se ha registrado principalmente en el estado de Veracruz, cerca del golfo de México. Flores-Primo et al. (2014) y López-Hernández (2015) reportaron la presencia de $V$. parahaemolyticus en las ostras de las lagunas costeras de Veracruz. Las lagunas costeras sobre la costa mexicana del Pacífico han sido menos estudiadas que las que se encuentran a lo largo de la línea de costa del golfo de México. En 2004, más de 1,230 casos clínicos de gastroenteritis por O3:K6 de $V$. parahaemolyticus fueron registrados después de la ingesta de camarones crudos provenientes del sistema lagunar Huizache-Caimanero (Sinaloa, México) (Cabanillas-Beltrán 2006). Las lagunas Caimanero y Huizache sostienen una pesquería artesanal de camarón importante, cuyos productos se distribuyen en restaurantes turísticos en el estado de Sinaloa y otros estados de México. El sistema lagunar HuizacheCaimanero se caracteriza por fluctuaciones extremas de salinidad (entre 3 y 60), un intervalo de temperatura del mar de 20 a $30^{\circ} \mathrm{C}$ y un aporte intermitente de nutrientes no nativos (De la Lanza y Rodríguez 1990). La sobrepesca y la eutrofización causada por efluentes cargados de nutrientes procedentes de las granjas camaroneras en el área de las lagunas Huizache y Caimanero han contribuido al cambio en las condiciones ecológicas naturales de las lagunas y, por tanto, han afectado la distribución y abundancia de las poblaciones microbianas, incluyendo la de las bacterias (Beltrán-Pimienta y Retamoza-Leyva 2003, Romero-Beltrán et al. 2014). La asociación de bacterias con efluentes ricos en nutrientes también ha sido observada en actividades agrícolas en otras partes de Sinaloa (Ahumada-Santos et al. 2014). El objetivo de este estudio fue determinar la presencia y distribución de V. parahaemolyticus, sus variantes toxigénicos y su relación con las variables ambientales en la laguna Caimanero. 
Rivas-Montaño et al.: Distribution of Vibrio parahaemolyticus in Caimanero Lagoon

\section{MATERIALS AND METHODS}

\section{Study areas and sampling sites}

The study was conducted in Caimanero Lagoon, which is part of the Huizache-Caimanero lagoon system. This lagoon is located approximately $25 \mathrm{~km}$ southeast of the port of Mazatlán, Sinaloa (Mexico), between $22^{\circ} 50^{\prime} 00^{\prime \prime} \mathrm{N}$ and $106^{\circ} 01^{\prime} 00^{\prime \prime} \mathrm{W}$. Water enters the lagoon by means of direct precipitation, drainage from surrounding streams, and inputs from a river through the marshes that connects the system to other rivers and the ocean (i.e., the Anonas Estuary with the Baluarte River and the Pacific Ocean, the Ostial Estuary with the Presidio River and the Pacific Ocean). Water level in the lagoon decreases through evaporation and because of the tidal flow through the Ostial Estuary. Caimanero Lagoon has a total surface area of $134 \mathrm{~km}^{2}$, with a maximum length of $19.6 \mathrm{~km}$, ranging widths of $2.5-9.5 \mathrm{~km}$, and ranging depths of $0.2-2.0 \mathrm{~m}$. The largest dimensions are seen only during the rainy season (Ramsar 2007). Climate in the region is tropical, with mean temperature of $22{ }^{\circ} \mathrm{C}$ and a marked rainy season from July to September that accounts for $80 \%$ of total rainfall $(1,000 \mathrm{~mm})$.

Five sampling sites were selected based on the ecological and hydrological characteristics of the lagoon and on the distance from the lagoon to shrimp farm discharges. Site $1\left(22^{\circ} 50^{\prime} 0.99^{\prime \prime} \mathrm{N}, 106^{\circ} 1^{\prime} 56.76^{\prime \prime} \mathrm{W}\right)$ is an area where the Baluarte River drains and seawater enters from the Pacific Ocean. Site $2\left(22^{\circ} 53^{\prime} 5.59^{\prime \prime} \mathrm{N}, 106^{\circ} 3^{\prime} 40.36^{\prime \prime} \mathrm{W}\right)$ was the primary access point to the lagoon and was located in an active fishing area (shrimp fishery cooperative). Site 3 $\left(22^{\circ} 57^{\prime} 6.67^{\prime \prime} \mathrm{N}, 106^{\circ} 4^{\prime} 21.33^{\prime \prime} \mathrm{W}\right)$ and site $4\left(22^{\circ} 57^{\prime} 6.67^{\prime \prime} \mathrm{N}\right.$, $\left.106^{\circ} 4^{\prime} 21.33^{\prime \prime} \mathrm{W}\right)$ were both affected by aquaculture activities (i.e., shrimp farming and production of shrimp larvae). Site $5\left(23^{\circ} 0^{\prime} 40.86^{\prime \prime} \mathrm{N}, 106^{\circ} 8^{\prime} 59.91^{\prime \prime} \mathrm{W}\right)$ corresponded to a zone influenced by the Huizache Lagoon and was the point farthest from the shrimp farming activities.

\section{Sampling}

Eight surveys were carried out from June 2014 to February 2016, and a total of 120 samples were collected (i.e., 40 water samples, 40 zooplankton samples, and 40 sediment samples). All samples were taken in duplicate. Water samples were collected $10 \mathrm{~cm}$ below the surface using a sterile plastic bag $(200 \mathrm{~mL})$. Zooplankton was collected from the surface runoff by towing a plankton net $(202 \mu \mathrm{m}$ mesh size, $0.30 \mathrm{~m}$ mouth diameter, $2 \mathrm{~m}$ length) provided by a flake collector $(10 \mathrm{~cm}$ in diameter, $20 \mathrm{~cm}$ in length) with 4 circular windows $(3 \mathrm{~cm}$ in diameter) for $5 \mathrm{~min}$. Each collector was covered with the same mesh as the plankton net to allow water release and concentrate zooplankton $(100 \mathrm{~mL})$. Sediment samples were collected with a dredge (jaws $10 \mathrm{~cm}$ in diameter, $150 \mathrm{~mL}$ volume capacity) below the aqua-sediment interface in the first $5 \mathrm{~cm}$ depth. Sediment samples of approximately $100 \mathrm{~g}$

\section{MATERIALES Y MÉTODOS}

\section{Áreas de estudio y sitios de muestreo}

El estudio se llevó a cabo en la laguna Caimanero, la cual forma parte del sistema lagunar Huizache-Caimanero. Esta laguna se localiza a aproximadamente $25 \mathrm{~km}$ al sureste del puerto de Mazatlán, Sinaloa (México), entre $22^{\circ} 50^{\prime} 00^{\prime \prime} \mathrm{N}$ y $106^{\circ} 01^{\prime} 00^{\prime \prime} \mathrm{W}$. La laguna recibe agua a través de la precipitación directa, del drenaje de arroyos circundantes y de los aportes de un río que atraviesa los humedales y conecta al sistema con otros ríos y el océano (i.e., el estuario Anonas con el río Baluarte y el océano Pacífico, el estuario Ostial con el río Presidio y el océano Pacífico). El nivel del agua en la laguna disminuye por la evaporación y por el flujo de las mareas a través del estuario Ostial. La laguna Caimanero tiene una superficie total de $134 \mathrm{~km}^{2}$, con una longitud máxima de $19.6 \mathrm{~km}$, anchuras que varían de 2.5 a $9.5 \mathrm{~km}$ y profundidades que oscilan entre 0.2 y $2.0 \mathrm{~m}$. Las dimensiones más grandes de los rangos mencionados sólo se presentan durante la temporada de lluvias (Ramsar 2007). El clima de la región es tropical, con una temperatura promedio de $22{ }^{\circ} \mathrm{C}$ y una marcada temporada de lluvias de julio a septiembre a la cual se le atribuye el $80 \%$ de la precipitación $(1,000 \mathrm{~mm})$.

Se seleccionaron 5 sitios de muestreo con base en las características ecológicas e hidrológicas de la laguna y la distancia de la laguna a las descargas de las granjas camaroneras. El sitio $1\left(22^{\circ} 50^{\prime} 0.99^{\prime \prime} \mathrm{N}, 106^{\circ} 1^{\prime} 56.76^{\prime \prime} \mathrm{W}\right)$ es un área en la cual desemboca el río Baluarte y entra agua del océano Pacífico. El sitio $2\left(22^{\circ} 53^{\prime} 5.59^{\prime \prime} \mathrm{N}, 106^{\circ} 3^{\prime} 40.36^{\prime \prime} \mathrm{W}\right)$ fue el acceso principal a la laguna y se localizó en un área de pesca activa (cooperativa camaronera). El sitio $3\left(22^{\circ} 57^{\prime} 6.67^{\prime \prime} \mathrm{N}\right.$, $\left.106^{\circ} 4^{\prime} 21.33^{\prime \prime} \mathrm{W}\right)$ y el sitio $4\left(22^{\circ} 57^{\prime} 6.67^{\prime \prime} \mathrm{N}, 106^{\circ} 4^{\prime} 21.33^{\prime \prime} \mathrm{W}\right)$ fueron sitios afectados por actividades acuícolas (i.e., cultivo de camarón y producción de larvas). El sitio $5\left(23^{\circ} 0^{\prime} 40.86^{\prime \prime} \mathrm{N}\right.$, $\left.106^{\circ} 8^{\prime} 59.91^{\prime \prime}\right)$ correspondió a la zona de influencia de la laguna Huizache y fue el punto más alejado de las actividades de las granjas camaroneras.

\section{Muestreo}

Se realizaron 8 muestreos desde junio de 2014 hasta febrero de 2016, y se recolectaron un total de 120 muestras (i.e., 40 muestras de agua, 40 de zooplancton y 40 de sedimento). Todas las muestras se tomaron por duplicado. Las muestras de agua se recolectaron a $10 \mathrm{~cm}$ por debajo de la superficie con una bolsa de plástico estéril $(200 \mathrm{~mL})$. El zooplancton se recolectó de la escorrentía superficial arrastrando durante $5 \mathrm{~min}$ una red de plancton (malla de $202 \mu \mathrm{m}$, boca de $0.30 \mathrm{~m}$ de diámetro, longitud de $2 \mathrm{~m}$ ) provista de un copo colector (10 $\mathrm{cm}$ de diámetro, $20 \mathrm{~cm}$ de largo) con 4 ventanas circulares $(3 \mathrm{~cm}$ de diámetro). Cada colector se cubrió con la misma malla que cubría la red de plancton para permitir la liberación del agua y la concentración del zooplancton $(100 \mathrm{~mL})$. Las muestras de sedimento se 
each were taken. All samples were placed in an ice chest and transported to the laboratory for analysis within $6 \mathrm{~h}$.

Environmental variables were measured at each site. Temperature and $\mathrm{pH}$ were measured with a mercury thermometer and a field potentiometer (Orion). Salinity was measured using a refractometer (Fisher) (salinity range of 0 to 50 ) with \pm 0.5 precision. A YSI- 50 -B oximeter was used to measure dissolved oxygen. All equipment was calibrated prior to use.

\section{Bacteriological analyses}

Assessment of the presence or absence of $V$. parahaemolyticus in the different types of samples was done by PCR using primers for the thermolabile haemolysine (tlh) gene and the methodology described by Kaysner and DePaola (2004). The procedure was carried out as follows. A $100-\mathrm{mL}$ water sample and a $50-\mathrm{mL}$ zooplankton sample were separately filtered through a polyethersulfone membrane (45 mm diameter, $0.2 \mu \mathrm{m}$ pore size; Supor-200 Pall Corporation) placed on a Millipore base. Each filter was then placed in $50 \mathrm{~mL}$ of Alkaline Peptone Water. For sediment analysis, $1 \mathrm{~g}$ of each sample was weighed, placed in a flask with $50 \mathrm{~mL}$ of Alkaline Peptone Water, and incubated at $35{ }^{\circ} \mathrm{C}$ for $24 \mathrm{~h}$. All samples were analyzed in duplicate. After incubation, $1 \mathrm{~mL}$ of the culture medium was extracted from flasks showing turbidity and placed in a $1.5-\mathrm{mL}$ tube for DNA extraction. The tube was vigorously mixed with a vortex mixer (Genie 2) and incubated at $95^{\circ} \mathrm{C}$ for $5 \mathrm{~min}$. The tube was mixed for a second time and placed on ice for $5 \mathrm{~min}$. Finally, the tube was centrifuged at 1,400 rpm for $5 \mathrm{~min}$, and the samples were stored at $-20{ }^{\circ} \mathrm{C}$ until use.

\section{Identification of the tlh, tdh, trh, and orf8 genes by conventional PCR}

The presence of the th gene (species-specific marker for V. parahaemolyticus) in samples with Alkaline Peptone Water was confirmed by PCR. The presence of the th gene was determined using a $12.5 \mu \mathrm{L}$ reaction mix that was prepared with $6.19 \mu \mathrm{L}$ of deionized water $(18 \Omega), 2.5 \mu \mathrm{L}$ of Green-Go-Tag Flexi buffer with $\mathrm{MgCl}_{2}$ (Promega; Madison, WI, USA), $0.25 \mu \mathrm{L}$ of dNTPs $(10 \mu \mathrm{L})$ (Promega Corporation; Madison, WI, USA), $1.25 \mu \mathrm{L}$ of forward primer $(10 \mu \mathrm{L}), 1.25 \mu \mathrm{L}$ of reverse primer $(10 \mu \mathrm{L}), 0.06 \mu \mathrm{L}$ of Taq polymerase (Axygen) $\left(0.025 \mathrm{U} \cdot \mu \mathrm{L}^{-1}\right)$, and $1.0 \mu \mathrm{L}$ of DNA from the sample that was to be analyzed. The samples that tested positive for the th gene were used for detection of toxigenic genes ( $t d h$ and trh), using the same component concentrations as the ones used for detection of the tlh gene. The primers used for the $t l h, t d h$, and trh genes were described by Bej et al. (1999). Amplification of the orf8 DNA segment was done with primers described by Myers et al. (2003). An Axygen MaxyGene thermocycler (Union City, CA, USA) was used to amplify the th gene and its toxigenic genes, with the following amplification recolectaron con una draga de cuchara $(10 \mathrm{~cm}$ de diámetro de cucharas, $150 \mathrm{~mL}$ de capacidad de volumen) por debajo de la interfaz agua-sedimento en los primeros $5 \mathrm{~cm}$ de profundidad. Se recolectaron muestras de sedimento de aproximadamente $100 \mathrm{~g}$ cada una. Todas las muestras se colocaron en una hielera y se transportaron al laboratorio para ser analizadas dentro de las $6 \mathrm{~h}$ subsecuentes.

Se midieron las variables ambientales en cada sitio. La temperatura y el $\mathrm{pH}$ se midieron con un termómetro de mercurio y un potenciómetro de campo (Orion). La salinidad se midió con un refractómetro (Fisher) (intervalo de salinidad de 0 a 50 ), con una precisión de \pm 0.5 . El oxígeno disuelto se midió con un oxímetro YSI-50-B. Todo el equipo se calibró antes de su uso.

\section{Análisis bacteriológico}

La presencia o ausencia de $V$. parahaemolyticus en los diferentes tipos de muestras se evaluó por medio de la reacción en cadena de la polimerasa (RCP) usando cebadores para el gen de la hemolisina termolábil (tlh) y la metodología descrita por Kaysner and DePaola (2004). El procedimiento se llevó acabo de la siguiente manera. Se filtraron, por separado, $100 \mathrm{~mL}$ de una muestra de agua y $50 \mathrm{~mL}$ de una muestra de zooplancton a través de una membrana de polietersulfona (45 mm de diámetro, tamaño de poro de $0.2 \mu \mathrm{m}$; Supor- 200 Pall Corporation) colocada sobre una base Millipore. Después, cada filtro se colocó en $50 \mathrm{~mL}$ de agua peptonada alcalina. Para el analizar el sedimento, $1 \mathrm{~g}$ de cada muestra fue pesado, colocado en un frasco con $50 \mathrm{~mL}$ de agua peptonada alcalina e incubado a $35^{\circ} \mathrm{C}$ por $24 \mathrm{~h}$. Todas las muestras se analizaron por duplicado. Después de la incubación, $1 \mathrm{~mL}$ del medio de cultivo fue extraído de los frascos que mostraron turbidez y colocado en un tubo de $1.5 \mathrm{~mL}$ para la extracción del ADN. El tubo se mezcló vigorosamente usando un agitador tipo vórtex (Genie 2) y se incubo a $95^{\circ} \mathrm{C}$ por $5 \mathrm{~min}$. El tubo se mezcló una segunda vez y se colocó en hielo por 5 min. Finalmente, el tubo se centrifugó a 1,400 rpm por 5 min, y las muestras se almacenaron a $-20^{\circ} \mathrm{C}$ hasta su uso.

\section{Identificación de los genes tlh, tdh, trh y orf8 por RCP convencional}

La presencia del gen th (marcador específico de la especie $V$. parahaemolyticus) en las muestras con agua peptonada alcalina se confirmó por medio de la RCP. La presencia del gen tlh se determinó con una mezcla de reacción de $12.5 \mu \mathrm{L}$ preparada con $6.19 \mu \mathrm{L}$ de agua desionizada (18 $\Omega$ ), $2.5 \mu \mathrm{L}$ del amortiguador Green-Go-Tag Flexi con $\mathrm{MgCl}_{2}$ (Promega; Madison, WI, EUA), $0.25 \mu \mathrm{L}$ de dNTP $(10 \mu \mathrm{L})$ (Promega Corporation; Madison, WI, EUA), $1.25 \mu \mathrm{L}$ de cebador directo $(10 \mu \mathrm{L}), 1.25 \mu \mathrm{L}$ de cebador inverso $(10 \mu \mathrm{L}), 0.06 \mu \mathrm{L}$ de polimerasa Taq (Axygen) $\left(0.025 \mathrm{U} \cdot \mu \mathrm{L}^{-1}\right)$ y $1.0 \mu \mathrm{L}$ de ADN de la muestra a analizar. Las muestras que resultaron positivas para el gen th fueron utilizadas para detectar genes toxigénicos 
conditions: denaturation cycle at $94^{\circ} \mathrm{C}$ for $10 \mathrm{~min}, 35$ cycles at $94{ }^{\circ} \mathrm{C}$ for $1 \mathrm{~min}$, annealing at $58^{\circ} \mathrm{C}$ for $1 \mathrm{~min}$, extension at $72{ }^{\circ} \mathrm{C}$ for $2 \mathrm{~min}$, and final extension at $72{ }^{\circ} \mathrm{C}$ for $10 \mathrm{~min}$. The annealing temperature for the orf 8 gene primers was modified to $60{ }^{\circ} \mathrm{C}$. To visualize the obtained products, electrophoresis on a $1.2 \%$ agarose $(\mathrm{w} / \mathrm{v})$ gel was carried out with a TAE $1 \times$ buffer $(40 \mathrm{mM}$ Tris acetate, $1 \mathrm{mM}$ EDTA, $\mathrm{pH}$ 8.0) and $0.5 \mu \mathrm{L}$ of GelRed (10,000X BIOTIUM) in an electrophoresis chamber (Enduro 10.10 horizontal Gel Box, $10 \times 10 \mathrm{~cm}$, Labnet) at $90 \mathrm{~V}$ for $40 \mathrm{~min}$. Electrophoresis results were observed in a transilluminator with a UVP lamp. Molecular weight markers with size range of 100-3,000 bp (Axygen Biosciences, CA, USA) were used. Control strains were obtained from the Collection of Aquatic Important Microorganisms (CAIM), which was provided by the Research Center for Food and Development in Mazatlán, Sinaloa (Mexico). Positive controls were CAIM 320 for the tlh gene, CAIM 1772 for the $t d h$ and trh genes, and CAIM 1400 for the orf8 gene. A reaction mixture with no DNA was used as a negative control. Only samples with duplicate sequence-specific amplifications were considered positive for $V$. parahaemolyticus.

\section{Statistical analysis}

A one-way analysis of variance (ANOVA) was used to determine significant differences in the presence of the th gene among sampling sites. One-way ANOVA was also used to evaluate significant differences in the monthly variation of environmental variables (i.e., temperature, salinity, $\mathrm{pH}$, and dissolved oxygen) and the th gene. The analyses were implemented in SigmaPlot 11.0. Spearman's correlation coefficient was used to determine the relationship between the frequency of the th gene indicative of $V$. parahaemolyticus and the environmental variables. The contribution of environmental parameters to the frequency of the th gene indicative of $V$. parahaemolyticus was analyzed using a principal component analysis, which was carried out with XLSTAT v2017.1. The level of significance was $P<0.05$.

\section{Results}

\section{Detection of the th gene and toxigenic genes}

The tlh gene was isolated from all the samples. Frequency was highest during the dry season (June 2014, February 2015, May 2015, and February 2016), followed by the rainy season (September 2014 and 2015). The highest proportion was found in zooplankton samples $(65 \%)$, compared to the water $(57 \%)$ and sediment (50\%) samples. With respect to sampling sites, the highest th gene frequency (37\%) occurred at site 4 , but it was not significantly different from frequencies at the other sites $(P=0.752)$ (Table 1$)$. (tdh y trh) empleando las mismas concentraciones de los componentes que se utilizaron para determinar la presencia del gen $t h$. Los cebadores que se usaron para los genes tlh, tdh y trh fueron descritos por Bej et al. (1999). Para la amplificación del segmento de ADN orf8, se utilizaron los cebadores descritos por Myers et al. (2003). Se usó un termociclador MaxyGene de Axygen (Union City, CA, EUA) para amplificar el gen tlh y sus genes toxigénicos, con las siguientes condiciones para la amplificación: un ciclo de desnaturalización a $94{ }^{\circ} \mathrm{C}$ por $10 \mathrm{~min}, 35$ ciclos a $94^{\circ} \mathrm{C}$ por 1 min, alineamiento a $58{ }^{\circ} \mathrm{C}$ por $1 \mathrm{~min}$, extensión a $72{ }^{\circ} \mathrm{C}$ por 2 min y extensión final a $72{ }^{\circ} \mathrm{C}$ por $10 \mathrm{~min}$. La temperatura de alineamiento de los cebadores para el gen orf 8 se modificó a $60^{\circ} \mathrm{C}$. Para visualizar los productos obtenidos, se empleó la electroforesis en gel de agarosa al $1.2 \%(\mathrm{p} / \mathrm{v})$ con un amortiguador TAE $1 \times$ (40 mM de Tris-acetato, $1 \mathrm{mM}$ de AEDT, $\mathrm{pH}$ 8.0) y $0.5 \mu \mathrm{L}$ de GelRed (10,000X BIOTIUM) en una cámara de electroforesis (cámara horizontal de geles $10 \times 10 \mathrm{~cm}$ modelo Enduro 10.10, Labnet) a $90 \mathrm{~V}$ por $40 \mathrm{~min}$. Los resultados de la electroforesis se visualizaron con un transiluminador con lámpara UVP. Se usaron marcadores de peso molecular de 100-3,000 pb (Axygen Biosciences, CA, EUA). Las cepas de control provenientes de la Colección de Microorganismos de Importancia Acuática (CAIM, por sus siglas en inglés) fueron proporcionadas por el Centro de Investigación en Alimentación y Desarrollo, unidad Mazatlán, Sinaloa (México). Los controles positivos fueron CAIM 320 para el gen tlh, CAIM 1772 para los genes $t d h$ y trh, y CAIM 1400 para el gen orf8. Se utilizó una mezcla de reacción sin $\mathrm{ADN}$ como control negativo. Sólo las muestras con amplificaciones específicas por duplicado se consideraron positivas para V. parahaemolyticus.

\section{Análisis estadístico}

Se usó un análisis de varianza (ANDEVA) de una vía para determinar las diferencias significativas en la presencia del gen tlh entre los sitios de muestreo. El ANDEVA de una vía también se usó para evaluar las diferencias significativas en la variación mensual de las variables ambientales (i.e., temperatura, salinidad, $\mathrm{pH}$ y oxígeno disuelto) y el gen tlh. Los análisis se implementaron con el software SigmaPlot 11.0. Se usó el coeficiente de correlación de Spearman para determinar la relación entre la frecuencia del gen tlh indicador de $V$. parahaemolyticus y las variables ambientales. La contribución de los parámetros ambientales a la frecuencia del gen tlh indicador de $V$. parahaemolyticus se analizó por medio de un análisis de componentes principales, el cual se llevó a cabo con XLSTAT v2017.1. El nivel de significancia fue $P<0.05$.

\section{Resultados}

\section{Detección del gen tlh y los genes toxigénicos}

Se aisló el gen tlh de todas las muestras. La frecuencia fue más alta durante la temporada seca (junio de 2014, febrero 
The $t d h$ and trh toxigenic genes were detected in zooplankton samples collected in September 2014 (sites 3 and 4) and February 2016 (sites 3-5). The trh gene was detected only in water samples collected in February 2016 (sites 1-3) (Table 1). The tdh gene was not detected in water, but the trh and orf 8 genes were found in 13\% (3/23) and $17 \%(4 / 23)$ of the positive samples, respectively. In zooplankton, tdh, trh, and orf8 were detected in $19 \%$ $(5 / 26), 4 \%(1 / 26)$, and $8 \%(2 / 26)$ of the samples, respectively. In the sediment, $t d h$ was detected in $5 \%(1 / 20)$ of the samples and orf8 in $10 \%(1 / 20)$ of the positive samples, but trh was not detected.

\section{Environmental parameters and correlation with the th gene}

Enviromental variables showed temporal variations in Caimanero Lagoon (Table 2). Seawater temperature varied between 24.7 and $31.1{ }^{\circ} \mathrm{C}$. Values for $\mathrm{pH}$ varied between 7.1 and 9.4, with no significant differences. Salinity was high in June 2014 (mean $=41.20)$, with significant differences $(P<0.05)$ between all months except for May 2015 and February 2016. Dissolved oxygen was variable, trending between 4.6 and $13.8 \mathrm{mg} \cdot \mathrm{L}^{-1}$. In May 2015 , dissolved oxygen concentration was high (mean $\left.=10.10 \mathrm{mg} \cdot \mathrm{L}^{-1}\right)$ and significantly different $(P<0.05)$ from concentrations in September 2014 and February and September 2015.

A principal component analysis was used to analyze the contribution of environmental parameters to the presence of the th gene in all the samples from the lagoon. The relation between environmental parameters and the th gene explained $69.59 \%$ of total variance. Salinity accounted for $15.78 \%$ of the variability in the presence of the th gene, $\mathrm{pH}$ accounted for $31.45 \%$, dissolved oxygen accounted for $37.55 \%$, and temperature accounted for $15.21 \%$. Salinity levels were significantly associated with the presence of the th gene (Fig. 1). The environmental parameters considered in this study to possibly affect the presence or absence of V. parahaemolyticus are listed in Table 3 . The presence of the bacterium in the samples was significantly correlated with salinity, but no correlation was observed between the th gene and temperature (Table 3).

\section{Discussion}

The distribution of the th gene indicative of $V$. parahaemolyticus and its relation to environmental parameters in the coastal lagoons in northwest Mexico are little known. The presence of the th gene in Caimanero Lagoon was detected throughout the survey. It was detected with less frequency at site 1 (water entry to the lagoon system), which was not affected by aquaculture activities or major salinity fluctuations owing to its geographic location. The lowest tlh gene frequency in Caimanero Lagoon de 2015, mayo de 2015 y febrero de 2016), seguida de la temporada de lluvias (septiembre de 2014 y 2015). La mayor proporción se observó en las muestras de zooplancton (65\%), en comparación con las muestras de agua (57\%) y sedimento $(50 \%)$. En cuanto a los sitios de muestreo, la frecuencia más alta del gen tlh (37\%) se registró para el sitio 4, pero no fue significativamente diferente de las frecuencias registradas para los otros sitios $(P=0.752)$ (Tabla 1$)$.

Los genes toxigénicos tdh y trh se detectaron en las muestras de zooplancton recolectadas en septiembre de 2014 (sitios 3 y 4) y febrero de 2016 (sitios 3-5). El gen trh se detectó sólo en las muestras de agua recolectadas en febrero de 2016 (sitios 1-3) (Tabla 1). El gen $t d h$ no se detectó en el agua, pero los genes trh y orf 8 se encontraron en el $13 \%(3 / 23)$ y el $17 \%(4 / 23)$ de las muestras positivas, respectivamente. En el zooplancton, $t d h$, trh y orf8 se detectaron en el $19 \%(5 / 26)$, el $4 \%(1 / 26)$ y el $8 \%(2 / 26)$ de las muestras, respectivamente. En el sedimento, $t d h$ se detectó en el $5 \%(1 / 20)$ de las muestras y orf8 en el $10 \%(1 / 20)$ de las muestras positivas, pero trh no se detectó.

\section{Parámetros ambientales y su correlación con el gen tlh}

Las variables ambientales mostraron variaciones temporales en la laguna Caimanero (Tabla 2). Los valores del pH variaron entre 7.1 y 9.4, sin diferencias significativas. La salinidad fue alta en junio de 2014 (promedio $=41.20$ ), con diferencias significativas $(P<0.05)$ entre todos los meses excepto mayo de 2015 y febrero de 2016. El oxígeno disuelto varió con tendencias de entre 4.6 y $13.8 \mathrm{mg} \cdot \mathrm{L}^{-1}$. En mayo de 2015, la concentración de oxígeno disuelto fue más alta (promedio $=10.10 \mathrm{mg} \cdot \mathrm{L}^{-1}$ ) y significativamente diferente $(P<0.05)$ de las concentraciones en septiembre de 2014 y en febrero y septiembre de 2015.

Se usó un análisis de componentes principales para analizar la contribución de los parámetros ambientales a la presencia del gen th en todas las muestras de la laguna. La relación entre los parámetros ambientales y el gen th explicó el $69.59 \%$ de la varianza total. La salinidad explicó el $15.78 \%$ de la variabilidad en presencia del gen tlh, el $\mathrm{pH}$ explicó el $31.45 \%$, el oxígeno disuelto explicó el 37.55\% y la temperatura explicó el $15.21 \%$. Los niveles de salinidad se relacionaron significativamente con la presencia del gen tlh (Fig.1). Los parámetros ambientales que en este estudio se consideraron como posibles factores que afectan la presencia o ausencia de $V$. parahaemolyticus se listaron en la Tabla 3. La presencia de la bacteria en las muestras estuvo significativamente correlacionada con la salinidad, pero no se observó una correlación entre el gen tlh y la temperatura (Tabla 3).

\section{Discusión}

La distribución del gen th indicador de la especie $V$. parahaemolyticus y su relación con los parámetros 
Table 1. Presence of the th gene indicative of Vibrio parahaemolyticus, and toxigenic and pandemic genes in environmental samples from Caimanero Lagoon. $0=$ not detected.

Tabla 1. Presencia del gen tlh indicador de Vibrio parahaemolyticus, y de genes toxigénicos y pandémicos en muestras ambientales de la laguna Caimanero. $0=$ no detectado.

\begin{tabular}{|c|c|c|c|c|c|c|c|c|c|c|c|c|c|c|c|c|c|}
\hline \multirow[b]{2}{*}{ Sampling } & \multirow[b]{2}{*}{ Site } & \multicolumn{4}{|c|}{ Water } & \multicolumn{4}{|c|}{ Zooplankton } & \multicolumn{4}{|c|}{ Sediment } & \multicolumn{4}{|c|}{ Total } \\
\hline & & tlh & $t d h$ & trh & orf8 & tlh & $t d h$ & trh & orf8 & tlh & $t d h$ & trh & orf8 & tlh & $t d h$ & trh & orf8 \\
\hline \multirow[t]{5}{*}{ June 2014} & 1 & + & - & - & + & + & - & - & - & + & + & - & - & 3 & 1 & 0 & 1 \\
\hline & 2 & 0 & & & & + & - & - & - & + & - & - & + & 2 & 0 & 0 & 1 \\
\hline & 3 & + & - & - & + & 0 & & & & + & - & - & - & 2 & 0 & 0 & 1 \\
\hline & 4 & + & - & - & - & + & - & - & - & 0 & & & & 2 & 0 & 0 & 0 \\
\hline & 5 & + & - & - & - & + & - & - & - & + & - & - & - & 3 & 0 & 0 & 0 \\
\hline \multirow[t]{5}{*}{ September 2014} & 1 & 0 & & & & 0 & & & & 0 & & & & 0 & & & \\
\hline & 2 & 0 & & & & 0 & & & & 0 & & & & 0 & & & \\
\hline & 3 & 0 & & & & + & + & - & - & 0 & & & & 1 & 1 & 0 & 0 \\
\hline & 4 & 0 & & & & + & + & - & - & 0 & & & & 1 & 1 & 0 & 0 \\
\hline & 5 & 0 & & & & 0 & & & & 0 & & & & 0 & & & \\
\hline \multirow[t]{5}{*}{ November 2014} & 1 & 0 & & & & + & - & - & - & 0 & & & & 1 & 0 & 0 & 0 \\
\hline & 2 & + & - & - & + & + & - & - & - & + & - & - & + & 3 & 0 & 0 & 2 \\
\hline & 3 & 0 & & & & + & - & - & - & 0 & & & & 1 & 0 & 0 & 0 \\
\hline & 4 & + & - & - & - & + & - & - & - & + & - & - & - & 3 & 0 & 0 & 0 \\
\hline & 5 & 0 & & & & + & - & - & - & 0 & & & & 1 & 0 & 0 & 0 \\
\hline \multirow[t]{5}{*}{ February 2015} & 1 & + & - & - & - & + & - & - & - & + & - & - & - & 3 & 0 & 0 & 0 \\
\hline & 2 & + & - & - & - & + & - & - & - & + & - & - & - & 3 & 0 & 0 & 0 \\
\hline & 3 & + & - & - & + & + & - & - & + & + & - & - & - & 3 & 0 & 0 & 2 \\
\hline & 4 & + & - & - & - & + & - & - & - & + & - & - & - & 3 & 0 & 0 & 0 \\
\hline & 5 & + & - & - & - & + & - & - & + & + & - & - & - & 3 & 0 & 0 & 1 \\
\hline \multirow[t]{5}{*}{ May 2015} & 1 & + & - & - & - & 0 & & & & + & - & - & - & 2 & 0 & 0 & 0 \\
\hline & 2 & + & - & - & - & + & - & - & - & + & - & - & - & 3 & 0 & 0 & 0 \\
\hline & 3 & + & - & - & - & + & - & - & - & 0 & & & & 2 & 0 & 0 & 0 \\
\hline & 4 & - & - & - & - & + & - & - & - & 0 & & & & 1 & 0 & 0 & 0 \\
\hline & 5 & + & - & - & - & + & - & - & - & + & - & - & - & 3 & 0 & 0 & 0 \\
\hline \multirow[t]{5}{*}{ September 2015} & 1 & 0 & & & & 0 & & & & 0 & & & & 0 & & & \\
\hline & 2 & 0 & & & & 0 & & & & 0 & & & & 0 & & & \\
\hline & 3 & 0 & & & & 0 & & & & + & - & - & - & 1 & 0 & 0 & 0 \\
\hline & 4 & 0 & & & & 0 & & & & 0 & & & & 0 & & & \\
\hline & 5 & 0 & & & & 0 & & & & + & - & - & - & 1 & 0 & 0 & 0 \\
\hline \multirow[t]{5}{*}{ November 2015} & 1 & 0 & & & & + & - & - & - & 0 & & & & 1 & 0 & 0 & 0 \\
\hline & 2 & + & - & - & - & 0 & & & & 0 & & & & 1 & 0 & 0 & 0 \\
\hline & 3 & + & - & - & - & + & - & - & - & 0 & & & & 2 & 0 & 0 & 0 \\
\hline & 4 & + & - & - & - & 0 & & & & + & - & - & - & 2 & 0 & 0 & 0 \\
\hline & 5 & 0 & & & & 0 & & & & + & - & - & - & 1 & 0 & 0 & 0 \\
\hline \multirow[t]{6}{*}{ February 2016} & 1 & + & - & + & - & 0 & & & & 0 & & & & 1 & 0 & 1 & 0 \\
\hline & 2 & + & - & + & - & + & - & - & - & 0 & & & & 2 & 0 & 1 & 0 \\
\hline & 3 & + & - & + & - & + & + & - & - & 0 & & & & 2 & 1 & 1 & 0 \\
\hline & 4 & + & - & - & - & + & + & - & - & + & - & - & - & 3 & 1 & 0 & 0 \\
\hline & 5 & + & - & - & - & + & + & + & - & + & - & - & - & 3 & 1 & 1 & 0 \\
\hline & Total & 23 & 0 & 3 & 4 & 26 & 5 & 1 & 2 & 20 & 1 & 0 & 2 & 69 & 6 & 4 & 8 \\
\hline
\end{tabular}


Table 2. Mean values $( \pm \mathrm{SD})$ for environmental parameters in Caimanero Lagoon.

Tabla 2. Valores promedio ( \pm desviación estándar) de los parámetros ambientales en la laguna Caimanero.

\begin{tabular}{|c|c|c|c|c|c|c|c|c|}
\hline $\begin{array}{l}\text { Environmental } \\
\text { parameters }\end{array}$ & \multicolumn{3}{|c|}{2014} & \multicolumn{4}{|c|}{2015} & $\frac{2016}{\text { February }}$ \\
\hline Temperature $\left({ }^{\circ} \mathrm{C}\right)$ & $31.1 \pm 1.8^{\mathrm{ab}}$ & $31.8 \pm 1.1^{\mathrm{b}}$ & $27.3 \pm 1.3^{\mathrm{ab}}$ & $27.7 \pm 1.1^{\mathrm{ab}}$ & $24.7 \pm 2.4^{\mathrm{a}}$ & $30.5 \pm 1.3^{\mathrm{ab}}$ & $24.8 \pm 3.1^{\mathrm{a}}$ & $26.0 \pm 4.8^{\mathrm{ab}}$ \\
\hline Salinity & $41.2 \pm 18.8^{b}$ & $10.0 \pm 7.1^{\mathrm{ac}}$ & $11.4 \pm 6.0^{\mathrm{ac}}$ & $22.2 \pm 7.3^{\mathrm{ac}}$ & $31.2 \pm 13.3^{\mathrm{b}}$ & $8.0 \pm 5.7^{\mathrm{a}}$ & $18.6 \pm 6.8^{\mathrm{ac}}$ & $27.8 \pm 6.3^{\mathrm{bc}}$ \\
\hline $\mathrm{pH}$ & $8.5 \pm 0.3^{\mathrm{a}}$ & $7.7 \pm 0.3^{\mathrm{a}}$ & $8.5 \pm 0.7^{\mathrm{a}}$ & $8.3 \pm 0.3^{\mathrm{a}}$ & $8.0 \pm 0.3^{\mathrm{a}}$ & $7.7 \pm 0.4^{\mathrm{a}}$ & $8.5 \pm 0.4^{\mathrm{a}}$ & $8.0 \pm 0.5^{\mathrm{a}}$ \\
\hline
\end{tabular}

a, beans with different letters are significantly different $(P<0.05)$ between seasons.

was recorded in September, when heavy rainfall caused an abrupt decrease in salinity (salinity $=8$ ). These results suggest that $V$. parahaemolyticus can be affected by low salinity.

Several studies have shown that when salinity decreases during the rainy season in a tropical zone, the concentration of $V$. parahaemolyticus increases (Reyes-Velázquez et al. 2010, Machado and Bordalo 2016). However, in this study the frequency of $V$. parahaemolyticus was higher during the dry season. Collin and Rehnstam-Holm (2011) obtained similar results, as they found V. parahaemolyticus in $73.2 \%$ of their samples at the end of the dry season. Flores-Primo et al. (2014) observed high densities of the th gene in oysters during the dry season. Deepanjali et al. (2005) observed that water temperature in the tropical coastal regions of India was always optimal and did not significantly affect V. parahaemolyticus. Esteves et al. (2015) indicated that, in a Medetirranean coastal lagoon, salinity was crucial for the development of Vibrio, compared to small changes in temperature. In the present study, temperature did not correlate with the presence of the tlh gene by site because there were little temperature variations in the lagoon. Similar results were reported by Turner et al. (2014), who showed that, for plankton, the th gene in V. parahaemolyticus did not correlate with temperature. Whitaker et al. (2010) reported that $V$. parahaemolyticus grows best when $\mathrm{pH}$ is neutral; however, Parveen et al. (2008) found low correlation between $V$. parahaemolyticus and this parameter $\left(r^{2}=0.3514\right.$, $P<0.085)$. In the present study, a positive correlation between $\mathrm{pH}$ and the presence of the th gene was found only for site 3. Variations in $\mathrm{pH}$ were normal in this study; therefore, $\mathrm{pH}$ could not atypically effect the th gene.

The highest th gene frequency was detected in zooplankton. Several studies have also found higher frequencies of the th gene in zooplankton than in water (Baffone et al. 2006, Turner et al. 2009, Caburlotto et al. 2010, Johnson et al. 2010, Martinez-Urtaza et al. 2012, Rehnstam-Holm et al. 2014). Vibrio parahaemolyticus can survive in sediments during the coldest months of the year, incorporating itself back into the water column when temperature rises in the summer (DePaola et al. 1994, Fukushima and Seki 2004, Böer et al. 2013). However, Caimanero Lagoon is in a tropical ambientales en las lagunas costeras del noroeste de México son poco conocidas. La presencia del gen tlh en la laguna Caimanero se detectó durante todo el muestreo. Se detectó con menor frecuencia en el sitio 1 (entrada de agua al sistema lagunar), que no fue afectado por actividades acuícolas o grandes fluctuaciones en la salinidad debido a su localización geográfica. La frecuencia más baja del gen tlh en la laguna Caimanero se registró en septiembre, cuando se presentaron precipitaciones abundantes que causaron una disminución abrupta en la salinidad (salinidad = 8). Estos resultados sugieren que $V$. parahaemolyticus puede ser afectada por niveles bajos de salinidad.

Diversos estudios han demostrado que cuando la salinidad disminuye durante la temporada de lluvias en la zona tropical, la concentración de V. parahaemolyticus incrementa (Reyes-Velázquez et al. 2010, Machado y Bordalo 2016). Sin embargo, en este estudio, la frecuencia de V. parahaemolyticus fue mayor durante la temporada seca. Collin y Rehnstam-Holm (2011) obtuvieron resultados similares, ya que encontraron V. parahaemolyticus en el $73.2 \%$ de sus muestras al final de la temporada seca. Flores-Primo et al. (2014) observaron densidades altas del gen th en ostras durante la temporada seca. Deepanjali et al. (2005) observaron que la temperatura del agua en las regiones costeras tropicales de la India se mantuvo óptima y no afectó a V. parahaemolyticus de manera significativa. Esteves et al. (2015) indicaron que, en una laguna costera mediterránea, la salinidad es crucial para el desarrollo de Vibrio, en comparación con los pequeños cambios de temperatura. En el presente estudio, la temperatura del agua no se correlacionó con la presencia del gen th por sitio debido a que la temperatura en la laguna varió poco. Turner et al. (2014) reportaron resultados similares, en los cuales mostraron que en el plancton el gen th en $V$. parahaemolyticus no se correlacionó con la temperatura. Whitaker et al. (2010) reportaron que $V$. parahaemolyticus crece mejor con un $\mathrm{pH}$ neutral; sin embargo, Parveen et al. (2008) encontraron baja correlación entre V. parahaemolyticus y este parámetro $\left(r^{2}=0.3514\right.$, $P<0.085)$. En el presente estudio se encontró una correlación positiva entre el $\mathrm{pH}$ y la presencia del gen th únicamente en el sitio 3. La variación del pH fue normal en este 
zone where temperature variations are small, and this is why $V$. parahaemolyticus was detected throughout the study period. The results of the present study are consistent with the findings by Johnson et al. (2010) and Vezzulli et al. (2013).

The $t d h$ gene was detected at a higher frequency in zooplankton taken from sites affected by aquaculture activity. The presence of pathogenic genes in this study was low (i.e., in less than $10 \%$ of the samples), and previous studies in this area have reported similar results (Cabanillas-Beltrán et al. 2006, Velasco 2007, Sánchez 2016). However, VelazquezRoman et al. (2012) and Hernández-Díaz et al. (2015) respectively reported $52.0 \%$ and $65.3 \%$ of pathogenic genes in strains that were isolated from environmental samples taken from coastal areas in Sinaloa. This increase in the percentage of pathogenic genes was probably due to the high number of samples analyzed and to the selective isolation of V. parahaemolyticus.

Nasu et al. (2000) indicated that serotypes O3:K6 produce $t d h$ and enconde a single orf 8 gene; however, we found samples that tested positive for the orf 8 gene but negative for the tdh gene. Likewise, other studies have reported samples that tested positive for the th gene (species-specific), negative for the toxigenic genes (tdh, trh), and positive for the gene encoding the serotype O3:K6 (orf8) (Nair et al. 2007, Kam et al. 2008, Velazquez-Roman et al. 2012, Mala et al. 2016). Hara-Kudo et al. (2003) found $t d h$-negative and O3:K6-positive strains and suggested that these strains may have been variants that diverged from the ancestor of the present pandemic strains, which may have lost the $t d h$ gene as they adapted to the environment and thus lost their virulence. On the other hand, Velazquez-Roman et al. (2014) mentioned that in some countries of the Americas there were reported cases of gastroenteritis due to pandemic strains of $\mathrm{O} 3: \mathrm{K} 6$ and its serovariants.

The years 2014 and 2015 were affected by an El Niño event, with atypical changes in temperature and precipitation in September $2014(228.0 \mathrm{~mm})$ and September 2015 $(474.5 \mathrm{~mm})$, indicating salinity variations at almost every site in the lagoon. Enviromental changes caused by climatic events such as El Niño have a direct impact on Vibrio populations because of the increase in temperature and changes in the ecology and hydrology of the systems (Ceccarelli and Colwell 2014). In the present study, water temperature in Caimanero Lagoon fluctuated slightly, but salinity showed the highest fluctuation and was the most important factor determining the presence of the tlh gene. These results clearly indicate that flood events can strongly affect V. parahaemolyticus abundance. This is the first time that an abrupt decrease in $V$. parahaemolyticus abundance following the rainy season and the concomitant decrease in salinity has been recorded in situ.

In conclusion, this study establishes the importance of environmental parameters affecting the distribution and presence of the th gene indicative of $V$. parahaemolyticus. Our results also indicate the optimal niches for the estudio; por lo tanto, el $\mathrm{pH}$ no pudo afectar al gen th de manera atípica.

La mayor frecuencia del gen tlh se detectó en el zooplancton. Varios estudios también han encontrado mayores frecuencias del gen tlh en el zooplancton que en el agua (Baffone et al. 2006, Turner et al. 2009, Caburlotto et al. 2010, Johnson et al. 2010, Martinez-Urtaza et al. 2012, Rehnstam-Holm et al. 2014). Vibrio parahaemolyticus puede sobrevivir en el sedimento durante los meses más fríos del año e incorporarse en la columna de agua cuando la temperatura incrementa en el verano (DePaola et al. 1994, Fukushima y Seki 2004, Böer et al. 2013). Sin embargo, la laguna Caimanero se ubica en una zona tropical sin variaciones grandes de temperatura y, por tanto, V. parahaemolyticus fue detectado durante todo el periodo de estudio. Los resultados del presente estudio concuerdan con los hallazgos reportados por Johnson et al. (2010) y Vezzulli et al. (2013).

El gen $t d h$ se detectó con mayor frecuencia en el zooplancton muestreado en los sitios afectados por actividades acuícolas. La presencia de los genes patogénicos en

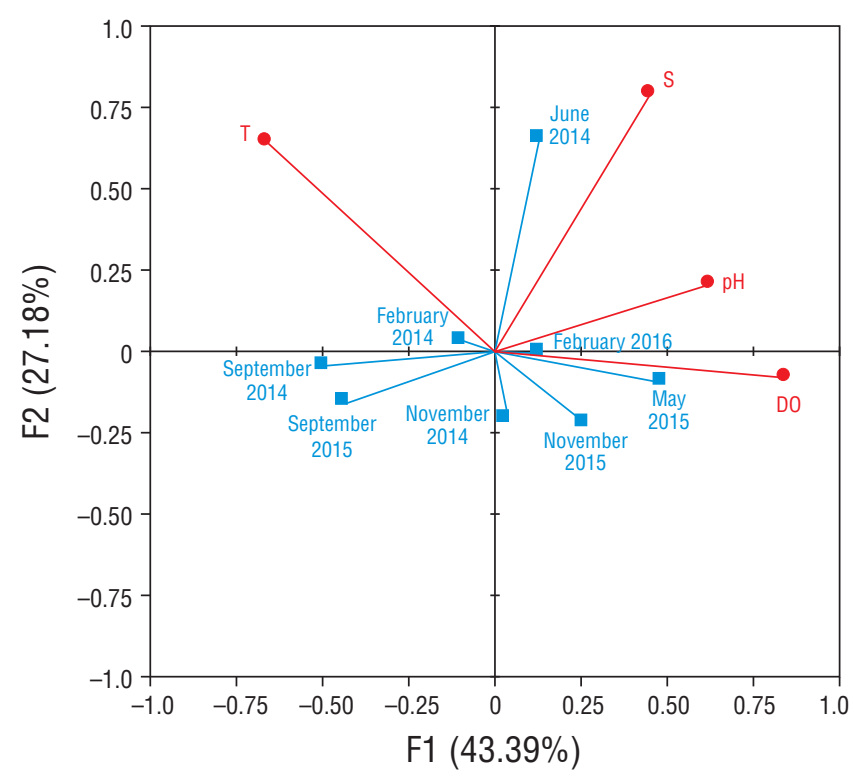

Figure 1. Principal component analysis of the environmental parameters affecting the presence of the th gene. Red vectors indicate environmental parameters $(\mathrm{S}=$ salinity, $\mathrm{T}=$ temperature $\left[{ }^{\circ} \mathrm{C}\right], \mathrm{DO}=$ dissolved oxygen $\left.\left[\mathrm{mg} \cdot \mathrm{L}^{-1}\right]\right)$. Blue vectors indicate presence of Vibrio parahaemolyticus (tlh) in all samples (water, sediments, and zooplankton). Variables with vectors projecting on the same plane were considered to be positively correlated.

Figura 1. Análisis de componentes principales de los parámetros ambientales que afectan la presencia del gen th. Los vectores rojos indican los parámetros ambientales $(\mathrm{S}=$ salinidad, $\mathrm{T}=$ temperatura $\left[{ }^{\circ} \mathrm{C}\right], \mathrm{DO}=$ oxígeno disuelto $\left.\left[\mathrm{mg} \cdot \mathrm{L}^{-1}\right]\right)$. Los vectores azules indican la presencia de Vibrio parahaemolyticus (tlh) en todas las muestras (agua, sedimentos y zooplancton). Se consideró que las variables que se proyectaron en el mismo plano se correlacionaron positivamente. 
Table 3. Spearman correlation between the th gene and the environmental parameters at the different sampling sites $(P<0.05)$.

Tabla 3. Correlación de Spearman entre el gen tlh y los parámetros ambientales en los diferentes sitios de muestreo $(P<0.05)$.

\begin{tabular}{lcccc}
\hline Site & Temperature $\left({ }^{\circ} \mathrm{C}\right)$ & Salinity & $\mathrm{pH}$ & Dissolved oxygen $\left(\mathrm{mg} \cdot \mathrm{L}^{-1}\right)$ \\
\hline 1 & $0.018(P<0.963)$ & $0.794(P<0.048)$ & $0.482(P<0.302)$ & $-0.441(P<0.302)$ \\
2 & $-0.510(P<0.236)$ & $0.505(P<0.267)$ & $0.566(P<0.200)$ & $0.359(P<0.444)$ \\
3 & $-0.235(P<0.582)$ & $0.726(P<0.058)$ & $0.848(P<0.011)$ & $0.183(P<0.665)$ \\
4 & $-0.346(P<0.389)$ & $0.222(P<0.619)$ & $0.321(P<0.462)$ & $-0.012(P<0.977)$ \\
5 & $-0.350(P<0.389)$ & $0.760(P<0.037)$ & $0.100(P<0.840)$ & $0.250(P<0.536)$ \\
\hline
\end{tabular}

survival of this species and identify the effects of changes in salinity due to rainfall on the presence of the th gene, highlighting that a single environmental parameter alone should not be investigated to determine the presence and distribution of $V$. parahaemolyticus. The results confirm that the ecology of $V$. parahaemolyticus varies with respect to geographic locations. The presence of the pathogenic tdh and trh genes and the orf8 gene suggests that constant health surveillance is needed to prevent local public health problems.

\section{ACKNOWLEDGMENTS}

This work was supported by the National Institute of Technology of Mexico (project no. 6114.17-P), the National Council for Science and Technology (Mexico, grant no. 1395601), and project INFR-2015/251448. The authors thank Diana Sánchez-Zambrano and Carmen Bolán for their assistance.

\section{REFERENCES}

Ahumada-Santos YP, Báez-Flores ME, Díaz-Camacho SP, UribeBeltrán MJ, López-Angulo G, Vega-Aviña R, Chávez-Duran FA, Montes-Avila J, Carranza-Díaz O, Möder M, et al. 2014. Spatiotemporal distribution of the bacterial contamination of agricultural and domestic wastewater discharged to a drainage ditch $($ Sinaloa, Mexico) $=$ Distribución espaciotemporal de la contaminación bacteriana del agua residual agrícola y doméstica descargada a un canal de drenaje (Sinaloa, México). Cienc. Mar. 40(4): 277-289. https://doi.org/10.7773/cm.v40i4.2456

Baffone W, Tarsi R, Pane L, Campana R, Repetto B, Mariottini GL, Pruzzo C. 2006. Detection of free-living and plankton-bound vibrios in coastal waters of the Adriatic Sea (Italy) and study of their pathogenicity-associated properties. Environ. Microbiol. 8(7): 1299-1305. https://doi.org/10.1111/j.1462-2920.2006.01011.x

Bej AK, Patterson DP, Brasher CW, Vickery MCL, Jones DD, Kaysner CA. 1999. Detection of total and hemolysin-producing Vibrio parahaemolyticus in shellfish using multiplex PCR amplification of $t l, t d h$ and trh. J. Microbiol. Methods 36(3): 215-225.

https://doi.org/10.1016/s0167-7012(99)00037-8 este estudio fue baja (i.e., en menos del $10 \%$ de las muestras), y los estudios anteriores en esta área reportaron resultados similares (Cabanillas-Beltrán et al. 2006, Velasco 2007, Sánchez 2016). Sin embargo, Velazquez-Roman et al. (2012) y Hernández-Díaz et al. (2015) reportaron que obtuvieron, respectivamente, el $52.0 \%$ y $65.3 \%$ de los genes patogénicos en las cepas aisladas de las muestras ambientales tomadas de las zonas costeras de Sinaloa. Este incremento en el porcentaje de genes patogénicos probablemente se debió al gran número de muestras analizadas y al aislamiento selectivo de $V$. parahaemolyticus.

Nasu et al. (2000) indicaron que los serotipos O3:K6 producen $t d h$ y codifican un único gen orf8; sin embargo, nosotros encontramos muestras que resultaron positivas para el gen orf8, pero negativas para el gen $t d h$. Del mismo modo, otros estudios han registrado muestras que resultaron positivas para el gen tlh (específico de la especie), negativas para los genes toxigénicos $(t d h / t r h)$ y positivas para el gen que codifica para el serotipo O3:K6 (orf8) (Nair et al. 2007, Kam et al. 2008, Velazquez-Roman et al. 2012, Mala et al. 2016). Hara-Kudo et al. (2003) encontraron cepas negativas para $t d h$ y positivas para $\mathrm{O} 3: \mathrm{K} 6$ y sugirieron que estas cepas pudieron haber sido variantes que divergieron del ancestro de las cepas pandémicas actuales, las cuales pudieron haber perdido el gen tdh conforme se adaptaron al ambiente y, por tanto, perdieron su virulencia. Por otro lado, Velazquez-Roman et al. (2014) mencionaron que en algunos países del continente americano se han reportado casos de gastroenteritis causados por las cepas pandémicas de O3:K6 y sus serovariantes.

Los años 2014 y 2015 fueron afectados por un evento de El Niño, con cambios atípicos de temperatura y precipitación durante septiembre de $2014(228.0 \mathrm{~mm})$ y septiembre de 2015 (474.5 mm), lo cual sugiere que hubo variaciones de salinidad en casi todos los sitios de la laguna. Los cambios ambientales causados por los eventos climáticos como El Niño tienen un impacto directo en las poblaciones de $V$. parahaemolyticus debido al incremento en la temperatura y a los cambios en la ecología e hidrología de los sistemas (Ceccarelli y Colwell 2014). En el presente estudio, la temperatura en la laguna Caimanero fluctuó poco, pero la 
Beltrán-Pimienta R, Retamoza-Leyva S. 2003. Evaluación de uso de purina en la captura de camarón en la laguna El Caimanero, Sinaloa, México. Instituto Nacional de la Pesca. Secretaría de Agricultura, Ganadería, Desarrollo Rural, Pesca y Alimentación. Sinaloa, México, 21 pp.

Böer SI, Heinemeyer EA, Luden K, Erler R, Gerdts G, Janssen F, Brennholt N. 2013. Temporal and spatial distribution patterns of potentially pathogenic Vibrio spp. at recreational beaches of the German North Sea. Microb. Ecol. 65(4): 1052-1067. https://doi.org/10.1007/s00248-013-0221-4

Cabanillas-Beltrán H, Llausás-Magaña E, Romero R, Espinoza A, García-Gasca A, Nishibuchi M, Ishibashi M, Gomez-Gil B. 2006. Outbreak of gastroenteritis caused by the pandemic Vibrio parahaemolyticus O3:K6 in Mexico. FEMS Microbiol. Lett. 265(1): 76-80. https://doi.org/10.1111/j.1574-6968.2006.00475.x

Caburlotto G, Haley BJ, Lleò MM, Huq A, Colwell RR. 2010. Serodiversity and ecological distribution of Vibrio parahaemolyticus in the Venetian Lagoon, Northeast Italy. Environ. Microbiol. Rep. 2(1): 151-157. https://doi.org/10.1111/j.1758-2229.2009.00123.x

Cariani A, Piano A, Consolandi C, Severgnini M, Castiglioni B, Caredda G, Candela M, Serratore P, De Bellis G, Tinti F. 2012. Detection and characterization of pathogenic vibrios in shellfish by a Ligation Detection Reaction-Universal Array approach. Int. J. Food Microbiol. 153(3): 474-482. https://doi.org/10.1016/j.ijfoodmicro.2011.11.010

Ceccarelli D, Colwell RR. 2014. Vibrio ecology, pathogenesis, and evolution. Front. Microbiol. 5:256. https://doi.org/10.3389/fmicb.2014.00256

Chung-Saint L, Tser-Sheng L, Din-Yuan Y, Yi-Cheng Su, YungHsiang T. 2016. Identification of Vibrio parahaemolyticus in seafood by multiplex PCR. J. Aquatic Food Product. Technol. 25(8): 1301-1310. https://doi.org/10.1080/10498850.2015.1056864

Collin B, Rehnstam-Holm AS. 2011. Occurrence and potential pathogenesis of Vibrio cholerae, Vibrio parahaemolyticus and Vibrio vulnificus on the South Coast of Sweden. FEMS Microbiol. Ecol. 78(2): 306-313. https://doi.org/10.1111/j.1574-6941.2011.01157.x

De la Lanza G, Rodríguez Medina M. 1990. Regional Characterization of the Caimanero Lagoon, Sinaloa Mexico, through some geochemical variables $=$ Caracterización regional de la Laguna de Caimanero, Sinaloa, México. Cienc. Mar. 16(3): 27-44. https://doi.org/10.7773/cm.v16i3.701

Deepanjali A, Kumar HS, Karunasagar I, Karunasagar I. 2005. Seasonal variation in abundance of total and pathogenic Vibrio parahaemolyticus bacteria in oysters along the southwest coast of India. Appl. Environ. Microbiol. 71(7): 3575-3580. https://doi.org/10.1128/aem.71.7.3575-3580.2005

DePaola A, Capers GM, Alexander D. 1994. Densities of Vibrio vulnificus in the intestines of fish from the U.S. Gulf Coast. App. Enviro. Microb. 60(3): 984-988.

Esteves K, Hervio-Heath D, Mosser T, Rodier C, Tournoud MG, Jumas-Bilak E, Colwell RR, Monfort P. 2015. Rapid proliferation of Vibrio parahaemolyticus, Vibrio vulnificus, and Vibrio cholerae during freshwater flash floods in French Mediterranean coastal lagoons. Appl. Environ. Microbiol. 81 (21): 7600-7609. https://doi.org/10.1128/aem.01848-15

[FAO/WHO] Food and Agriculture Organization of the United Nations/World Health Organization. 2011. Risk assessment of Vibrio parahaemolyticus in seafood: Interpretative summary and technical report. Microbiological Risk Assessment Series No. 16. [Accessed 12 June 2017] FAO, Rome. http://apps.who. int/iris/bitstream/10665/44566/1/9789241548175 eng.pdf salinidad mostró la mayor fluctuación y fue el factor más importante que determinó la presencia del gen th. Estos resultados indican que los eventos de inundación pueden afectar fuertemente la abundancia de V. parahaemolyticus. Esta es la primera vez que se ha registrado una disminución tan abrupta en la abundancia de V. parahaemolyticus in situ después de la temporada de lluvias y la disminución concomitante en la salinidad.

En conclusión, este estudio establece la importancia de los parámetros ambientales que afectan la distribución y la presencia del gen th indicador de $V$. parahaemolyticus. Nuestros resultados también indican los nichos óptimos para la supervivencia de esta especie e identifican los efectos de los cambios de salinidad inducidos por la precipitación en la presencia del gen $t l h$, lo cual demuestra que los parámetros ambientales no se deben investigar de manera individual para determinar la presencia y distribución de $V$. parahaemolyticus. Los resultados confirman que la ecología de $V$. parahaemolyticus varía con respecto a la ubicación geográfica. La presencia de los genes patogénicos tdh y trh y el gen orf8 sugiere que se necesita mantener una vigilancia sanitaria continua para prevenir problemas locales de salud pública.

\section{Agradecimientos}

Este trabajo recibió apoyo por parte del Tecnológico Nacional de México (proyecto no.6114.17-P), el Consejo Nacional de Ciencia y Tecnología (México, beca no. 1395601) y el proyecto INFR-2015/251448. Los autores agradecen el apoyo de Diana Sánchez Zambrano y Carmen Bolán.

Traducido al español por Claudia Michel-Villalobos

Flores-Primo A, Pardío-Sedas V, Lizarrága-Partida L, LópezHernández K, Uscanga-Serrano R, Flores-Hernández R. 2014. Seasonal abundance of total and pathogenic Vibrio parahaemolyticus isolated from American oysters harvested in Mandinga Lagoon system, Veracruz, Mexico: Implications for food safety. J. Food Prot. 77(7): 1069-1077.

https://doi.org/10.4315/0362-028x.jfp-13-482

Fukushima H, Seki R. 2004. Ecology of Vibrio vulnificus and Vibrio parahaemolyticus in brackish environments of the Sada River in Shimane Prefecture, Japan. FEMS Microbiol. Ecol. 48(2): 221-229.

https://doi.org/10.1016/j.femsec.2004.01.009

García K, Bastías R, Higuera G, Torres R, Mellado A, Uribe P, Espejo RT. 2013. Rise and fall of pandemic Vibrio parahaemolyticus serotype O3:K6 in southern Chile. Environ. Microbiol. 15(2): 527-534.

https://doi.org/10.1111/j.1462-2920.2012.02883.x

Gavilán RG, Martínez-Urtaza J. 2011. Factores ambientales vinculados con la aparición y dispersión de las epidemias de Vibrio en América del Sur. Rev. Peru. Med. Exp. Salud Pública 28(1): 109-115.

https://doi.org/10.1590/s1726-46342011000100017 
Givens CE, Bowers JC, DePaola A, Hollibaugh JT, Jones JL. 2014. Occurrence and distribution of Vibrio vulnificus and Vibrio parahaemolyticus - potential roles for fish, oyster, sediment and water. Lett. Appl. Microbiol. 58(6): 503-510. https://doi.org/10.1111/lam.12226

Hara-Kudo Y, Sugiyama K, Nishibuchi M, Chowdhury A, Yatsuyanagi J, Ohtomo Y, Saito A, Nagano H, Nishina T, Nakagawa H, et al. 2003. Prevalence of pandemic thermostable direct hemolysin-producing Vibrio parahaemolyticus O3:K6 in seafood and the coastal environment in Japan. Appl. Environ. Microbiol. 69(7): 3883-3891.

https://doi.org/10.1128/aem.69.7.3883-3891.2003

Hernández-Díaz LJ, Leon-Sicairos N, Velazquez-Roman J, FloresVillaseñor H, Guadron-Llanos AM, Martinez-Garcia JJ, Vidal JE, Canizalez-Roman A. 2015. A pandemic Vibrio parahaemolyticus O3:K6 clone causing most associated diarrhea cases in the Pacific Northwest coast of Mexico. Front. Microbiol. 6(221): 1-11. https://doi.org/10.3389/fmicb.2015.00221

Johnson CN. 2013. Fitness Factors in vibrios: A Mini-review. Microb. Ecol. 65(4): 826-851.

Johnson CN, Flowers AR, Noriea NF, Zimmerman AM, Bowers JC, DePaola A, Grimes DJ. 2010. Relationships between environmental factors and pathogenic vibrios in the northern Gulf of Mexico. Appl. Environ. Microbiol. 76(21): 7076-7084 https://doi.org/10.1128/aem.00697-10

Kam KM, Luey CKY, Parsons MB, Cooper KLF, Nair GB, Alam M, Islam MA, Cheung DTL, Chu YW, Ramamurthy T, et al. 2008. Evaluation and validation of a PulseNet standardized pulsed-field gel electrophoresis protocol for subtyping Vibrio parahaemolyticus: An International Multicenter Collaborative study. J. Clin. Microbiol. 46(8): 2766-2773.

https://doi.org/10.1128/jcm.00424-08

Kaysner CA, DePaola A Jr. 2004. BAM: Vibrio. US Food and Drug Administration, Bacteriological Analytical Manual, 8th ed. [Accessed 17 June 2017] Silver Spring (MD). http://www.fda. gov/Food/FoodScienceResearch/LaboratoryMethods/ ucm070830.htm

Letchumanan V, Chan KG, Lee LH. 2014. Vibrio parahaemolyticus: a review on the pathogenesis, prevalence, and advance molecular identification techniques. Front. Microbiol. 5(705): 1-13. https://doi.org/10.3389/fmicb.2014.00705

López-Hernández KM, Pardío-Sedas VT, Lizárraga-Partida L, Williams JJ, Martínez-Herrera D, Flores-Primo A, UscangaSerrano R, Rendón-Castro K. 2015. Environmental parameters influence on the dynamics of total and pathogenic Vibrio parahaemolyticus densities in Crassostrea virginica harvested from Mexico's Gulf coast. Mar. Pollut. Bull. 91(1): 317-329. https://doi.org/10.1016/j.marpolbul.2014.11.015

Machado A, Bordalo AA. 2016. Detection and quantification of Vibrio cholerae, Vibrio parahaemolyticus, and Vibrio vulnificus in coastal waters of Guinea-Bissau (West Africa). Ecohealth 13(2): 339-349. https://doi.org/10.1007/s10393-016-1104-1

Mala W, Alam M, Angkititrakul S, Wongwajana S, Lulitanond V, Huttayananont S, Kaewkes W, Faksri K, Chomvarin C. 2016. Serogroup, virulence, and molecular traits of Vibrio parahaemolyticus isolated from clinical and cockle sources in northeastern Thailand. Infect., Genet. Evol. 39: 212-218. https://doi.org/10.1016/j.meegid.2016.01.006

Martinez-Urtaza J, Blanco-Abad V, Rodriguez-Castro A, AnsedeBermejo J, Miranda A, Rodriguez-Alvarez MX. 2012. Ecological determinants of the occurrence and dynamics of Vibrio parahaemolyticus in offshore areas. ISME J. 6(5): 994-1006. http://dx.doi.org/10.1038/ismej.2011.156
Martinez-Urtaza J, Powell A, Jansa J, Castro RJL, Paz MO, García CM, Zamora LMJ, Pousa A, Faraldo VMJ, Trinanes J, et al. 2016. Epidemiological investigation of a foodborne outbreak in Spain associated with US West Coast genotypes of Vibrio parahaemolyticus. Springerplus 5(87): 1-8. https://doi.org/10.1186/s40064-016-1728-1

Miyoshi SI. 2013. Extracellular proteolytic enzymes produced by human pathogenic Vibrio species. Front. Microbiol. 4: 339. https://doi.org/10.3389/fmicb.2013.00339

Myers ML, Panicker G, Bej AK. 2003. PCR detection of a newly emerged pandemic Vibrio parahaemolyticus O3:K6 pathogen in pure cultures and seeded waters from the Gulf of Mexico. Appl. Environ. Microbiol. 69(4): 2194-2200. https://doi.org/10.1128/aem.69.4.2194-2200.2003

Nair GB, Ramamurthy T, Bhattacharya SK, Dutta B, Takeda Y, SackDA. 2007. Global dissemination of Vibrioparahaemolyticus serotype O3:K6 and its serovariants. Clin. Microbiol. Rev. 20(1): $39-48$. https://doi.org/10.1128/cmr.00025-06

Nasu H, Iida T, Sugahara T, Yamaichi Y, Park KS, Yokoyama K, Makino K, Shinagawa H, Honda T. 2000. A filamentous phage associated with recent pandemic Vibrio parahaemolyticus O3:K6 strains. J. Clin. Microbiol. 38(6): 2156-2161.

Ottaviani D, Leoni F, Rocchegiani E, Mioni R, Costa A, Virgilio S, Serracca L, Bove D, Canonico C, Di Cesare A, et al. 2013. An extensive investigation into the prevalence and the genetic and serological diversity of toxigenic Vibrio parahaemolyticus in Italian marine coastal waters. Environ. Microbiol. 15(5): 13771386. https://doi.org/10.1111/j.1462-2920.2012.02839.x

Paranjpye R, Hamel OS, Stojanovski A, Liermann M. 2012. Genetic diversity of clinical and environmental Vibrio parahaemolyticus strains from the Pacific northwest. Appl. Environ. Microbiol. 78(24): 8631-8638. https://doi.org/10.1128/aem.01531-12

Parte AC. 2018. LPSN-List of prokaryotic names with Standing in Nomenclature (bacterio.net), 20 years on. Int. J. Syst. Evol. Microbiol. 68: 1825-1829. http://dx.doi.org/10.1099/ijsem.0.002786

Parveen S, Hettiarachchi KA, Bowers JC, Jones JL, Tamplin ML, McKay R, Beatty W, Brohawn K, DaSilva LV, DePaola A. 2008. Seasonal distribution of total and pathogenic Vibrio parahaemolyticus in Chesapeake Bay oysters and waters. Int. J. Food Microbiol. 128(2): 354-361. https://doi.org/10.1016/j.ijfoodmicro.2008.09.019

Ramsar. 2007. Ramsar sites information Service. Laguna HuizacheCaimanero. [Accessed 06 October 2016] [Ramsar Secretariat]. http://rsis.ramsar.org/ris/1689.

Rehnstam-Holm AS, Atnur V, Godhe A. 2014. Defining the niche of Vibrio parahaemolyticus during pre- and post-monsoon seasons in the coastal Arabian Sea. Microb. Ecol. 67(1): 57-65. http://dx.doi.org/10.1007/s00248-013-0311-3

Reyes-Velázquez C, Castañeda-Chávez MR, Landeros-Sánchez C, Galaviz-Villa I, Lango-Reynoso F, Minguez-Rodríguez MM, Nikolskii-Gavrilov I. 2010. Pathogenic vibrios in the oyster Crassostrea virginica in the lagoon system of Mandinga, Veracruz, Mexico. Hidrobiológica 20(3): 238-245.

Romero-Beltrán E, Aldana-Flores G, Muñoz-Mejia EM, Medina -Osuna PM, Valdéz-Ledón P, Bect-Valdez JA, GasparDillanes MT, Huidobro-Campos L, Romero-Correa A, et al. 2014. Estudio de la calidad del agua y sedimento en lagunas costeras del estado de Sinaloa, México. Instituto Nacional de la Pesca, Secretaría de Agricultura, Ganadería, Desarrollo Rural, Pesca y Alimentación. Mazatlán, Sinaloa, México. 
Sánchez ZD. 2016. Incidencia, distribución espacio-temporal y toxigenia de serovariedades de Vibrio parahaemolyticus, en camarón blanco (Litopenaeus vannamei) de la laguna Caimanero, Sinaloa, México. MSc thesis. Instituto Tecnológico de Mazatlán, Mazatlán, Sinaloa, Mexico.

Turner JW, Good B, Cole D, Lipp EK. 2009. Plankton composition and environmental factors contribute to Vibrio seasonality. ISME J. 3(39): 1082-1092. https://doi.org/10.1038/ismej.2009.50

Turner JW, Malayil L, Guadagnoli D, Cole D, Lipp EK. 2014. Detection of Vibrio parahaemolyticus, Vibrio vulnificus and Vibrio cholerae with respect to seasonal fluctuations in temperature and plankton abundance. Environ. Microbiol. 16(4): 1019-1028. https://doi.org/10.1111/1462-2920.12246

Velasco API. 2007. Variación espacio-temporal de Vibrio parahaemolyticus total y toxigénico en el sistema lagunar Huizache-Caimanero, Sinaloa, México. MSc. thesis, Centro de Investigación en Alimentación y Desarrollo, Mazatlán, Sinaloa, Mexico.

Velazquez-Roman J, León-Sicairos N, Flores-Villaseñor H, Villafaña-Rauda S, Canizalez-Roman A. 2012. Association of Pandemic Vibrio parahaemolyticus O3:K6 present in the coastal environment of Northwest Mexico with cases of recurrent diarrhea between 2004 and 2010. Appl. Environ. Microbiol. 78(6): 1794-1803.

https://doi.org/10.1128/aem.06953-11

Velazquez-Roman J, León-Sicairos N, Hernández-Díaz L de J, Canizalez-Roman A. 2014. Pandemic Vibrio parahaemolyticus
O3:K6 on the American continent. Front. Cell. Infect. Microbiol. 3: $1-14$. https://doi.org/10.3389/fcimb.2013.00110

Vezzulli L, Colwell RR, Pruzzo C. 2013. Ocean warming and spread of pathogenic vibrios in the aquatic environment. Microb. Ecol. 65(4): 817-825.

https://doi.org/10.1007/s00248-012-0163-2

Wang R, Zhong Y, Gu X, Yuan J, Saeed AF, Wang S. 2015. The pathogenesis, detection, and prevention of Vibrio parahaemolyticus. Front. Microbiol. 6: 1-13. https://doi.org/10.3389/fmicb.2015.00144

Whitaker WB, Parent MA, Naughton LM, Richards GP, Blumerman SL, Boyd EF. 2010. Modulation of responses of Vibrio parahaemolyticus $\mathrm{O} 3: \mathrm{K} 6$ to $\mathrm{pH}$ and temperature stresses by growth at different salt concentrations. Appl. Environ. Microbiol. 76(14): 4720-4729.

https://doi.org/10.1128/aem.00474-10

Xu F, Ilyas S, Hall JA, Jones SH, Cooper VS, Whistler CA. 2015. Genetic characterization of clinical and environmental Vibrio parahaemolyticus from the Northeast USA reveals emerging resident and non-indigenous pathogen lineages. Front. Microbiol. 6. https://doi.org/10.3389/fmicb.2015.00272

Zhang L, Orth K. 2013. Virulence determinants for Vibrio parahaemolyticus infection. Curr. Opin. Microbiol. 16(1): 70-77. https://doi.org/10.1016/j.mib.2013.02.002

Received March 2017, accepted February 2018. 